\title{
Correction to: A novel coordination complex of platinum (PT) induces cell death in colorectal cancer by altering redox balance and modulating MAPK pathway
}

Khayal Al-Khayal ${ }^{1}$, Mansoor-Ali Vaali-Mohammed ${ }^{1}$, Mohammed Elwatidy ${ }^{2}$, Thamer Bin Traiki ${ }^{1}$, Omar Al-Obeed ${ }^{1}$, Mohammad Azam³, Zahid Khan', Maha Abdullaª and Rehan Ahmad ${ }^{1 *}$

Correction to: BMC Cancer 20, 685 (2020)

https://doi.org/10.1186/s12885-020-07165-w

Following publication of the original article [1], the authors identified a typesetting error in Fig. 2, whereby the full figure was not published. The complete Fig. 2 is published in this correction article and the original article [1] has been corrected.

\footnotetext{
Author details

${ }^{1}$ Colorectal Research Chair, Department of Surgery, King Saud University College of Medicine, PO Box 7805 (37), 11472 Riyadh, Saudi Arabia. ${ }^{2}$ College of Medicine Research Center, King Saud University College of Medicine, Riyadh 11472, Saudi Arabia. ${ }^{3}$ Department of Chemistry, College of Science, King Saud University, Riyadh 11451, Saudi Arabia. ${ }^{4}$ Genome Research Chair, Department of Biochemistry, College of Science, King Saud University,

Riyadh, Saudi Arabia.
}

Published online: 01 September 2020

\section{Reference}

1. Al-Khayal K, Vaali-Mohammed M, Elwatidy M, et al. A novel coordination complex of platinum (PT) induces cell death in colorectal cancer by altering redox balance and modulating MAPK pathway. BMC Cancer. 2020;20:685 https://doi.org/10.1186/s12885-020-07165-w.

The original article can be found online at https://doi.org/10.1186/s12885020-07165-w.

* Correspondence: arehan@ksu.edu.sa

${ }^{1}$ Colorectal Research Chair, Department of Surgery, King Saud University College of Medicine, PO Box 7805 (37), 11472 Riyadh, Saudi Arabia

Full list of author information is available at the end of the article

(c) The Author(s). 2020 Open Access This article is licensed under a Creative Commons Attribution 4.0 International License, which permits use, sharing, adaptation, distribution and reproduction in any medium or format, as long as you give appropriate credit to the original author(s) and the source, provide a link to the Creative Commons licence, and indicate if changes were made. The images or other third party material in this article are included in the article's Creative Commons licence, unless indicated otherwise in a credit line to the material. If material is not included in the article's Creative Commons licence and your intended use is not permitted by statutory regulation or exceeds the permitted use, you will need to obtain permission directly from the copyright holder. To view a copy of this licence, visit http://creativecommons.org/licenses/by/4.0/. The Creative Commons Public Domain Dedication waiver (http://creativecommons.org/publicdomain/zero/1.0/) applies to the data made available in this article, unless otherwise stated in a credit line to the data. 


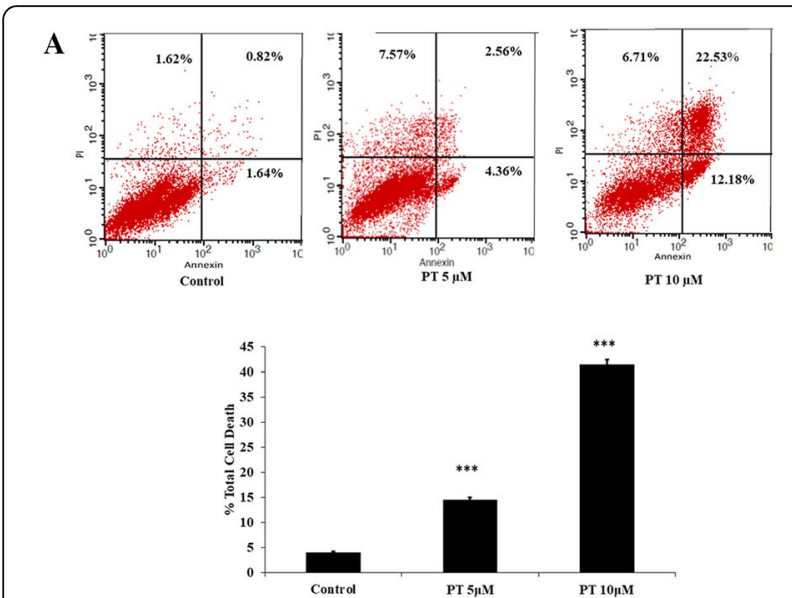

B
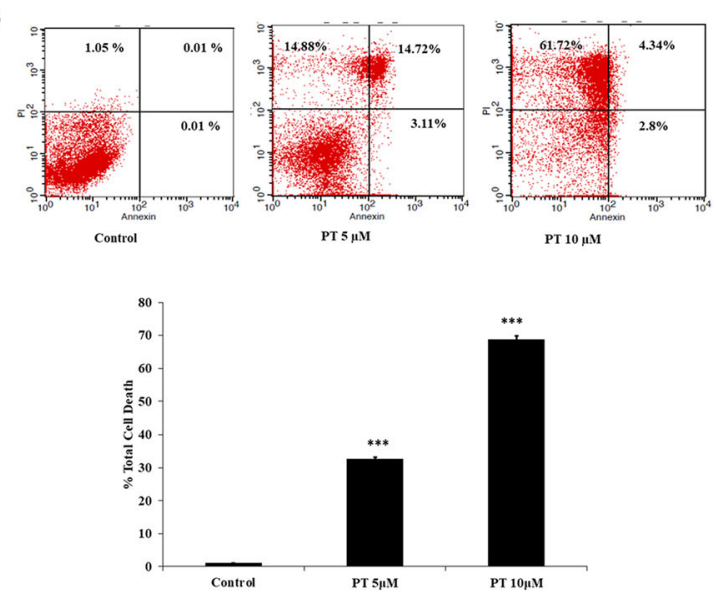

C
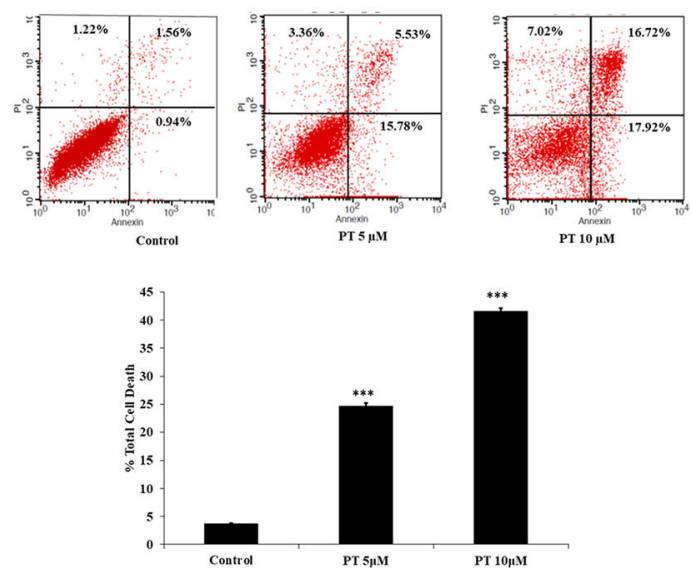

Fig. 2 PT induces apoptosis and cell cycle arrest. a HT-29 b SW480 c SW620 cells were treated with 5 and $10 \mu \mathrm{M}$ of PT for $24 \mathrm{~h}$. Total cell death including apoptosis and necrosis was analyzed by Annexin V/ PI staining using flow cytometry. $\mathbf{d}$ HT-29 and e SW620 cell cycle distribution was measured by PI staining using flow cytometry and the percentage of cell population was determined in the G0/G1, S and $\mathrm{G} 2 / \mathrm{M}$ phases. Results shown are representative of three independent experiment $(n=3) .{ }^{*} p<0.05,{ }^{* *} p<0.01,{ }^{* * *} p<0.001$ vs control

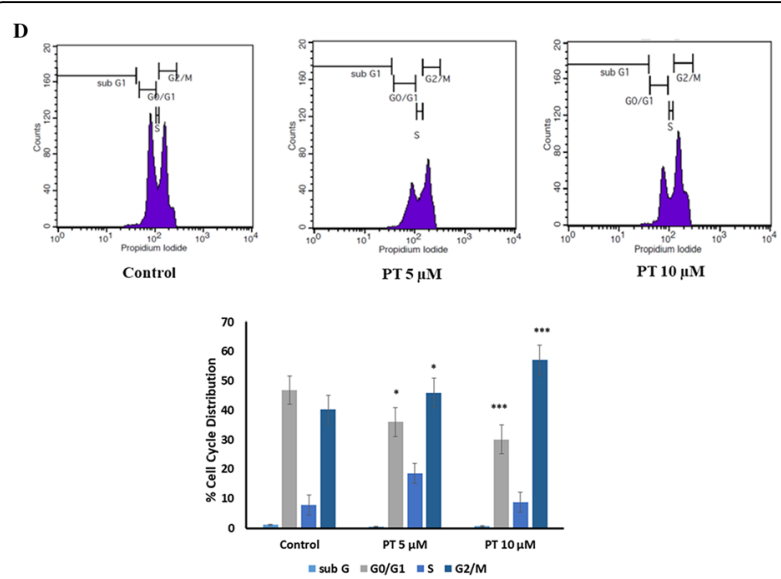

E
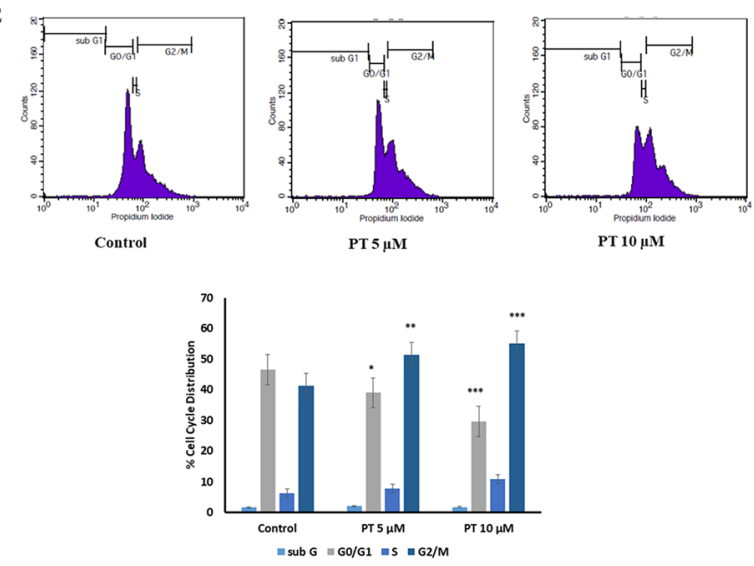

Fig. 2 PT induces apoptosis and cell cycle arrest. a HT-29 b SW480 c SW620 cells were treated with 5 and $10 \mu \mathrm{M}$ of PT for $24 \mathrm{~h}$. Total cell death including apoptosis and necrosis was analyzed by Annexin V/ PI staining using flow cytometry. $\mathbf{d}$ HT-29 and e SW620 cell cycle distribution was measured by PI staining using flow cytometry and the percentage of cell population was determined in the G0/G1, S and G2/M phases. Results shown are representative of three independent experiment $(n=3) .{ }^{*} p<0.05,{ }^{* *} p<0.01,{ }^{* * *} p<0.001$ vs control 